\title{
Role of Serum and Urinary Hepcidin in Young Females of Reproductive Age in North India
}

\author{
Shaveta Laller ${ }^{1}$ Seema Patel ${ }^{2}$ Deepa Haldar \\ 1 Department of Biochemistry, SGT Medical College and Hospital, \\ Gurugram, Haryana, India \\ 2 Department of Biochemistry, ESIC Medical College, Faridabad, \\ Haryana, India \\ ${ }^{3}$ Department of Biochemistry, Academic Block, Vardhman Mahavir \\ Medical College (VMMC and SJH), Ansari Nagar, New Delhi, India \\ J Lab Physicians 2022;14:175-182.
}

\begin{abstract}
Address for correspondence Seema Patel, MD, Department of Biochemistry, ESIC Medical College, Academic Block, Room No 202, Faridabad 121001, Haryana, India

(e-mail: dr.seema.aiims@gmail.com).
\end{abstract}

\begin{abstract}
Introduction Iron deficiency is one of the most common nutritional disorders in the world affecting young females of the reproductive age group. Indeed, an ideal screening test should be capable of identifying iron deficiency long before developing anemia. Henceforth, the present study was aimed to determine utility of hepcidin in iron deficiency and to see its correlation with different iron indices.

Methods This cross-sectional study was conducted in the Department of Biochemistry, SGT Medical College Hospital and Research Institute, Budhera, Gurugram, Haryana, India. It included 200 nonpregnant female students aged between 18 and 25 years. Estimation of hepcidin was by enzyme-linked immunosorbent assay. Quantitative estimation of serum iron, total iron-binding capacity (TIBC), and transferrin saturation was done via semi-autoanalyzer. Statistical analysis was done using SPSS v22.

Results The reference range of urinary hepcidin established in this study was 110 to $969 \mathrm{ng} / \mathrm{mg}$ creatinine (mean \pm standard deviation $328.3 \pm 195.07 \mathrm{ng} / \mathrm{mg}$ creatinine). Serum hepcidin and urinary hepcidin had a significant correlation with iron indices. Area under the curve of urinary hepcidin was obtained with best combination of diagnostic sensitivity $(82.6 \%)$ and specificity $(83.1 \%)$ at a cutoff value of $>15.7 \mathrm{ng} / \mathrm{mL}$ and $\leq 199 \mathrm{ng} / \mathrm{mg}$, respectively.

Keywords

- iron deficiency

- hepcidin

- transferrin

- young females

Conclusion Since ferritin, TIBC, transferrin saturation, and hepcidin each represent different aspects of iron metabolism, incorporating hepcidin in the present diagnostics and combined evaluation of these indices may accord enhanced clinical information. Hepcidin would help to stratify the vulnerable young healthy female population in early stages of iron deficiency and guide proper interventions to reduce morbidity.
\end{abstract}

published online September 17, 2021
DOI https://doi.org/

10.1055/s-0041-1735585. ISSN 0974-2727. (c) 2021. The Indian Association of Laboratory Physicians. All rights reserved.

This is an open access article published by Thieme under the terms of the Creative Commons Attribution-NonDerivative-NonCommercial-License, permitting copying and reproduction so long as the original work is given appropriate credit. Contents may not be used for commercial purposes, or adapted, remixed, transformed or built upon. (https://creativecommons.org/ licenses/by-nc-nd/4.0/)

Thieme Medical and Scientific Publishers Pvt. Ltd., A-12, 2nd Floor, Sector 2, Noida-201301 UP, India 


\section{Introduction}

Anemia is one of the most common nutritional disorder affecting 1.62 billion people worldwide. It is a public health problem affecting globally with major impact on health as well as socioeconomic development. Majority of the cases are seen in developing countries and among these, about half of the cases are due to iron deficiency (ID). It is estimated that around $52 \%$ of nonpregnant women of reproductive age are anemic in India. ${ }^{1,2}$ Maintenance of body iron status is an integral part of healthcare in young females of reproductive age group. Therefore, early detection of iron deficiency anemia (IDA) can lead to early intervention.

However, commonly used tests for diagnosis of iron status have their limitations. Ferritin is an indicator of iron stores, but it is an acute phase reactant, levels of which increase in inflammation. ${ }^{3}$ Similarly, soluble transferrin receptor (sTfR) levels reflect tissue ID, but are affected by erythropoietic activity. ${ }^{4}$ In addition, transferrin saturation (TSAT) levels may be influenced by inflammation and undergo diurnal variation. $^{5}$

Hepcidin-25, a 25-amino acid peptide hormone produced in the liver, is a central hub of systemic iron metabolism. ${ }^{6-9}$ Hepcidin downregulates iron absorption in duodenum and iron release from macrophage by modulating cellular iron export via ferroportin. ${ }^{10}$ Therefore, dysregulation of hepcidin production may lead to a variety of iron disorders. ${ }^{11}$ Hepcidin levels are reduced in patients with ID. Therefore, measurement of hepcidin levels may act as a determinant of iron bioavailability and an accurate indicator of physiological ID. Further, urinary hepcidin reflects an indirect assay of the circulating hormone level and a noninvasive method. Currently, hepcidin testing is not incorporated in routine iron profile markers in diagnostic laboratories. Blood and urinary hepcidin may provide as a screening tool for iron disorders. The present study was aimed to determine utility of hepcidin as an indicator of ID in nonpregnant nonanemic females and explore its association with other routine iron profile markers.

\section{Materials and Methods}

This cross-sectional study was conducted in the Department of Biochemistry, SGT Medical College Hospital and Research Institute, Budhera, Gurugram, Haryana. Two-hundred nonpregnant female students (age 18-25 years), who voluntarily participated in the study and had hemoglobin $>12 \mathrm{~g} \%$ and normal red blood cell (RBC) indices, were included in the study. However, female students on iron therapy, oral contraceptive pills, with chronic liver disease, any systemic illness, and acute or chronic infection were excluded from the study.

\section{Sample Collection and Processing}

Under strict aseptic precautions, $3 \mathrm{~mL}$ of venous blood was collected in ethylenediaminetetraacetic acid vacutainers that was used for the estimation of white blood cell, RBC, hemoglobin $[\mathrm{Hb}]$, hematocrit, mean corpuscular volume, mean corpuscular hemoglobin concentration [MCHC], platelet count, MCH via the SYSMEX KX 21 autoanalyzer and $5 \mathrm{~mL}$ was drawn in plain vacutainers that was centrifuged to separate serum. Quantitative estimation of serum iron, total iron-binding capacity (TIBC), transferrin, and sTfR was done by semiauto analyzer (ERBA CHEM 7) using Spinreact, S.A, Spain diagnostic kit. TSAT was calculated using the formula serum iron $\times 100 / \mathrm{TIBC}$. The serum was stored at $-20^{\circ} \mathrm{C}$ that was used to measure serum hepcidin level. Midstream urine samples were collected in the morning between 8 and $10 \mathrm{Am}$ to avoid diurnal variation. Then samples were centrifuged and were stored in aliquots at $-20^{\circ} \mathrm{C}$. To account for the variable dilution of urine samples, hepcidin concentration was normalized to urinary creatinine.

Hepcidin estimation was done by enzyme-linked immunosorbent assay (human hepcidin, ELISA Kit, Sincere Biotech Co., Ltd, Beijing, China). Purified human hepcidin antibody was used by the manufacturer to coat the microtiter plate wells to make solid-phase antibody. First, the serum sample was poured in the microtiter wells. Human hepcidin present in the serum sample combined with the coated antibody. Horse radish peroxidase (HRP) labeled antibody was then added to form antibody-antigen-enzyme-antibody complex. After washing, 3,3',5,5'-tetramethylbenzidine substrate solution was added that changed to blue color. HRP enzymecatalyzed reaction was terminated by the addition of a sulfuric acid solution and the color change was measured spectrophotometrically at a wavelength of $450 \mathrm{~nm}$. Thereafter, concentration of human hepcidin in the serum samples was determined by comparing the optical density of the samples to the standard curve.

\section{Statistical Analysis}

Data was analyzed using SPSS 20.0 version. Parametric data were represented by mean and standard deviation (SD), whereas nonparametric data were represented by median and quartile. Correlation between hepcidin and other parameters of iron status was determined by Spearman Correlation Test. Overall comparisons between serum and urinary hepcidin in each of the three ferritin groups (severe deficiency, moderate deficiency, and normal) were evaluated by Kruskal-Wallis test. Receiver operating curve (ROC) analysis and area under curve (AUC) were done to test the cutoff value of hepcidin in subclinically iron-deficient females. For all tests, a $p$-value of less than 0.05 was considered significant.

\section{Results}

Female students volunteering from SGT University conforming to the inclusion and exclusion criteria were screened for study. Screening was continued till the appropriate sample size for the study was reached. A total of 232 students were screened, of which 32 students were excluded because of low hemoglobin $<12 \mathrm{~g} / \mathrm{dL}$. Seven of the excluded students had body mass index (BMI) $\geq 30$. Thus, 200 healthy nonpregnant female university students were taken for the study. 
Table 1 Hematologic parameters and iron status of the study group based on iron profile parameters of study group

\begin{tabular}{|l|l|l|}
\hline Parameter & Mean \pm SD & Normal reference range \\
\hline Hemoglobin $(\mathrm{g} / \mathrm{dL})$ & $13.1 \pm 0.69$ & $12-15$ \\
\hline Hematocrit $(\%)$ & $40.1 \pm 2.11$ & $40-50$ \\
\hline RBC count $\left(\mathrm{millions} / \mathrm{mm}^{3}\right)$ & $4.14 \pm 0.261$ & $3.5-5.2$ \\
\hline $\mathrm{MCV}(\mathrm{fL})$ & $96.7 \pm 1.34$ & $80-100$ \\
\hline $\mathrm{MCH}(\mathrm{pg})$ & $31.6 \pm 0.42$ & $27-32$ \\
\hline $\mathrm{MCHC}(\mathrm{g} / \mathrm{dL})$ & $32.7 \pm 0.03$ & $30-35$ \\
\hline TLC $\left(\right.$ thousand/mm $\left.\mathrm{m}^{3}\right)$ & $8028.5 \pm 648.34$ & $4,000-10,000$ \\
\hline Serum iron $(\mu \mathrm{g} / \mathrm{dL})$ & $87.4 \pm 23.59$ & $50-150$ \\
\hline TIBC $(\mu \mathrm{g} / \mathrm{dL})$ & $425.1 \pm 16.38$ & $300-360$ \\
\hline Serum transferrin $(\mathrm{mg} / \mathrm{dL})$ & $297.3 \pm 25.62$ & $204-360$ \\
\hline TSAT $(\%)$ & $20.7 \pm 6.26$ & $30-50 \%)$ \\
\hline Serum ferritin $(\mu \mathrm{gm} / \mathrm{L})$ & $33.8 \pm 21.1$ & $50-200$ \\
\hline sTfR $(\mathrm{mg} / \mathrm{L})$ & 1.88 & $0.76-2.68$ \\
\hline Serum hepcidin $(\mathrm{ng} / \mathrm{mL})$ & $42.4 \pm 29.13$ & $12.14-139.89$ \\
\hline Urinary hepcidin $(\mathrm{ng} / \mathrm{mg}$ creatinine) & $328.3 \pm 195.07$ & $110-969$ \\
\hline
\end{tabular}

Abbreviations: MCHC, mean corpuscular hemoglobin concentration; RBC, red blood cell; TIBC, total iron-binding capacity; TLC, total leucocyte count; TSAT, transferrin saturation; SD, standard deviation; sTfR, soluble transferrin receptor.

Study population comprised of young healthy females with a mean age of 19.4 years and a mean BMI of 25.8. The hemoglobin, hematocrit, and red cell indices of all the subjects were within the normal reference range indicating no evidence of anemia. The total leucocytes count was also within the normal range ruling out any inflammation. Iron status of the study group has been ascertained based on various parameters as depicted in - Table $\mathbf{1}$. In - Table $\mathbf{2}$, comparison was made on the basis of different parameters, namely ferritin, TIBC, and TSAT. Serum hepcidin values had a statistically significant positive correlation with hemoglobin, serum iron, serum ferritin, and TSAT\% and a statistically significant negative correlation with sTfR, serum transferrin, and TIBC (-Fig. 1A, - Table 3).

Urinary hepcidin was in the range of 110 to $969 \mathrm{ng} / \mathrm{mg}$ creatinine in this population group with the mean and SD

Table 2 Discrimination between ID and NID based on parameters

\begin{tabular}{|l|l|l|l|}
\hline Parameter & ID/NID & \multicolumn{2}{|l|}{$\boldsymbol{n = 2 0 0}$} \\
\cline { 3 - 4 } & & $\boldsymbol{n}$ & $\%$ \\
\hline $\begin{array}{l}\text { TIBC }>425 \mathrm{mg} / \mathrm{dL} \\
\text { Serum ferritin } \leq 15 \mu \mathrm{g} / \mathrm{L}\end{array}$ & ID & 52 & 38 \\
\hline $\begin{array}{l}\text { TIBC } \leq 425 \mathrm{mg} / \mathrm{dL} \\
\text { Serum ferritin }>15 \mu \mathrm{g} / \mathrm{L}\end{array}$ & NID & 148 & 62 \\
\hline $\begin{array}{l}\text { TSAT } \leq 16 \% \\
\text { Serum ferritin } \leq 15 \mu \mathrm{g} / \mathrm{L}\end{array}$ & ID & 55 & 31.5 \\
\hline $\begin{array}{l}\text { TSAT }>16 \% \\
\text { Serum ferritin }>15 \mu \mathrm{g} / \mathrm{L}\end{array}$ & NID & 145 & 68.5 \\
\hline
\end{tabular}

Abbreviations: ID, iron deficiency; NID, non-iron deficiency; TIBC, total iron-binding capacity; TSAT, transferrin saturation. being $328.3 \pm 195.07$. Urinary hepcidin values also had a positive correlation with $\mathrm{Hb}$, serum iron, serum ferritin, and TSAT\% and a negative correlation with sTfR, serum transferrin, and TIBC; all correlations were highly statistically significant (-Table 4, - Fig. 2A). Urinary hepcidin on ROC showed higher discriminating power in evaluating iron status in young healthy women in the age group 18 to 25 years (AUC: 0.857 ) with best combination of diagnostic sensitivity (82.6\%) and specificity $(83.1 \%)$ at a cutoff value of $\leq 199 \mathrm{ng} / \mathrm{mg}$ creatinine (-Fig. 3). On evaluation, urinary hepcidin based on cutoffs derived from ROC curve $24.5 \%(49 / 200)$ of the students was found to be iron deficient ( - Table 5 ).

\section{Discussion}

ID is one of the most common nutritional deficiency and a significant public health problem worldwide largely affecting women and children. ${ }^{1}$ Hence, prompt diagnosis and early intervention are essential in women of reproductive age who are the bearers of future generations.

The progression to ID can be divided into three stages. First stage of negative iron balance where demand of iron exceeds the body's ability to absorb iron from the diet, during which serum ferritin levels decrease but the serum iron, TIBC, and red cell protoporphyrin levels remain within normal limits as long as iron stores are present and can replete. Second stage of iron-deficient erythropoiesis when iron stores become depleted and when serum ferritin levels fall to less than $15 \mu \mathrm{g} / \mathrm{L}$, the serum iron begins to fall, followed by increased TIBC, and TSAT falls to 15 to $20 \%$ impaired hemoglobin synthesis. Third stage of IDA, the Hb and hematocrit begin to fall. TSAT is 10 to $15 \%$ in this stage. Severe 


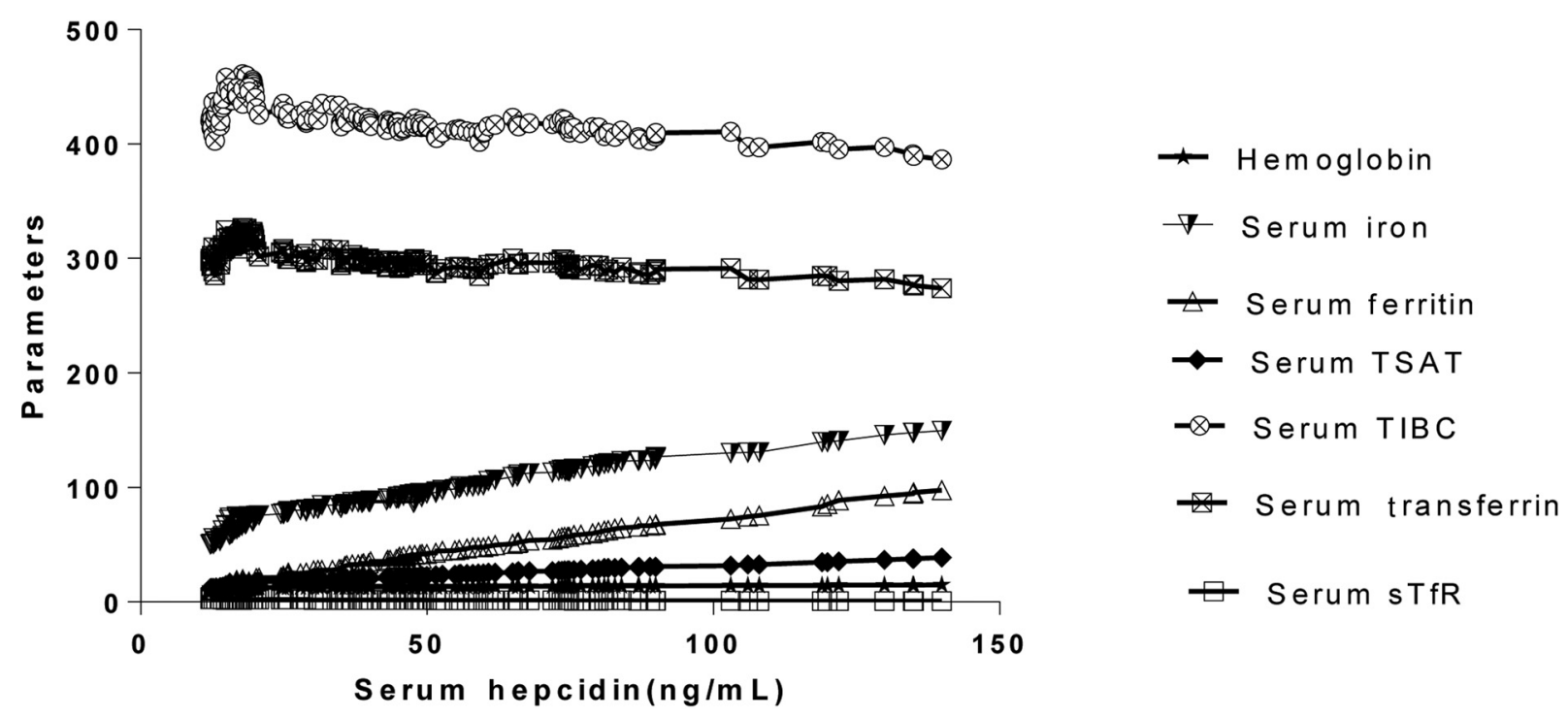

Fig. 1 Correlation between serum hepcidin with hemoglobin, serum iron, serum ferritin and TSAT\%, serum transferrin, TIBC, and sTfR. Parameters: Hemoglobin $(\mathrm{g} / \mathrm{dL})$; serum iron $(\mu \mathrm{g} / \mathrm{dL})$; serum ferritin $(\mu \mathrm{g} / \mathrm{L})$; serum transferrin saturation (TSAT\%); serum total iron-binding capacity $(T I B C)(\mu \mathrm{g} / \mathrm{dL})$; serum soluble transferrin receptor(sTfR) $(\mathrm{mg} / \mathrm{L})$.

anemia sets in with microcytosis, hypochromia, target cells, and poikilocytes in blood smear. ${ }^{12,13}$

Since available parameters have their own limitations, their synergism with markers like hepcidin would help to stratify the vulnerable population in early stages of negative iron balance or iron-deficient erythropoiesis and guide proper interventions to reduce morbidity. Hepcidin is the iron-regulatory hormone that plays a cardinal role to maintain homeostasis of extracellular iron concentrations. ${ }^{14} \mathrm{Hep}-$ cidin is produced by hepatocytes that undergoes posttranslational processing by prohormone convertase into its biologically active form hepcidin ( 25 amino acid peptide). ${ }^{15}$ It is rapidly cleared from the circulation. Urinary hepcidin levels correlate well with hepatic hepcidin mRNA. Hepcidin isoforms-20, -22 , and -25 are the three isoforms

Table 3 Correlation of serum hepcidin with traditional iron parameters

\begin{tabular}{|l|l|l|}
\hline & $\begin{array}{l}\text { Spearman } \\
\text { correlation } \\
\text { coefficient }(r)\end{array}$ & $p$-Value \\
\hline $\begin{array}{l}\text { Serum hepcidin vs. } \\
\text { hemoglobin }\end{array}$ & 0.962 & $<0.0001$ \\
\hline $\begin{array}{l}\text { Serum hepcidin vs. } \\
\text { serum iron }\end{array}$ & 0.977 & $<0.0001$ \\
\hline $\begin{array}{l}\text { Serum hepcidin vs. } \\
\text { serum transferrin }\end{array}$ & -0.813 & $<0.0001$ \\
\hline Serum hepcidin vs. TSAT \% & 0.986 & $<0.0001$ \\
\hline $\begin{array}{l}\text { Serum hepcidin vs. } \\
\text { serum ferritin }\end{array}$ & 0.994 & $<0.0001$ \\
\hline Serum hepcidin vs. STfR & -0.929 & $<0.0001$ \\
\hline Serum hepcidin vs. TIBC & -0.763 & $<0.0001$ \\
\hline
\end{tabular}

Abbreviations: TIBC, total iron-binding capacity; TSAT, transferrin saturation; sTfR, soluble transferrin receptor. excreted in urine of which hepcidin-25 and -20 are also found in serum. ${ }^{16,17}$ Hepcidin-25 isoform plays predominant role in iron regulation.

Hepcidin inhibits iron entry into the plasma compartment from main sources like the dietary absorption in the duodenum, release of recycled iron from macrophages, and the release of stored iron from hepatocytes by bonding to cellular iron efflux channel, ferroportin, inducing its internalization and lysosomal degradation. ${ }^{9} \mathrm{~N}$-terminally truncated breakdown products of hepcidin have been detectable in plasma and urine. Urine testing is chosen in preference to serum assays as it is less affected by diurnal variation and the noninvasive nature of sampling. ${ }^{16,17}$

The available methods for IDA diagnosis have their limitations. Ferritin as a marker is raised with age and in chronic

Table 4 Correlation of urinary hepcidin with traditional iron parameters

\begin{tabular}{|l|l|l|}
\hline & $\begin{array}{l}\text { Spearman } \\
\text { correlation } \\
\text { coefficient }(r)\end{array}$ & $p$-Value \\
\hline $\begin{array}{l}\text { Urinary hepcidin vs. } \\
\text { hemoglobin }\end{array}$ & 0.917 & $<0.0001$ \\
\hline $\begin{array}{l}\text { Urinary hepcidin vs. } \\
\text { serum iron }\end{array}$ & 0.861 & $<0.0001$ \\
\hline $\begin{array}{l}\text { Urinary hepcidin vs. } \\
\text { serum transferrin }\end{array}$ & -0.695 & $<0.0001$ \\
\hline Urinary hepcidin vs. TSAT \% & 0.864 & $<0.0001$ \\
\hline $\begin{array}{l}\text { Urinary hepcidin vs. } \\
\text { serum ferritin }\end{array}$ & 0.970 & $<0.0001$ \\
\hline Urinary hepcidin vs. STfR & -0.922 & $<0.0001$ \\
\hline Urinary hepcidin vs. TIBC & -0.694 & $<0.0001$ \\
\hline
\end{tabular}

Abbreviations: TIBC, total iron-binding capacity; TSAT, transferrin saturation; sTfR, soluble transferrin receptor. 


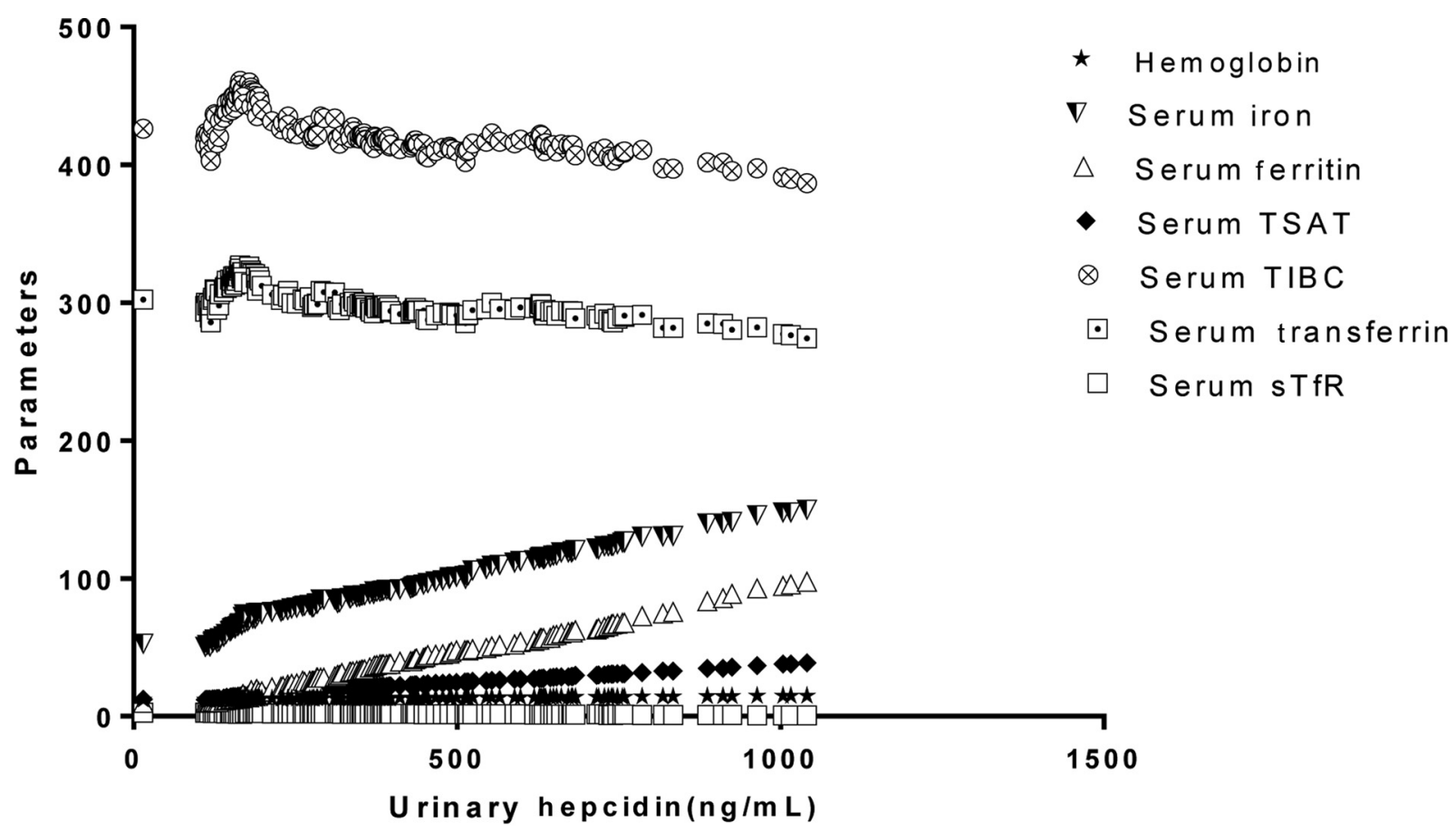

Fig. 2 Correlation between urinary hepcidin with hemoglobin, serum iron, serum ferritin, and transferrin saturation (TSAT\%), serum transferrin, total iron-binding capacity (TIBC), and soluble transferrin receptor (sTfR).

infections, malignancies, hepatitis, and hyperthyroidism; so, it is relatively less sensitive in detecting an early ID. ${ }^{18-20}$ Moreover, sTfR is affected by erythropoietic activity, whereas TSAT levels may be influenced by inflammation and diurnal variation. $^{4,5}$ Bone marrow aspiration for iron studies is an invasive procedure, nonpatient compliant, tedious, and requires aseptic condition; hence, it cannot frequently be used as a method of choice for the detection of iron-deficient anemia. ${ }^{21,22}$

The aim of this study was to determine utility of hepcidin as an indicator of ID in nonpregnant nonanemic females and observe its association with other routine iron profile markers that alter in early stages. The normal reference range of urinary hepcidin in young healthy females and cutoff value was determined.

It was observed in present study that serum iron levels in all the study group students were within the normal reference range. Since serum iron levels show diurnal fluctuation, an isolated serum iron determination is not quite useful to differentiate ID and IDA. ${ }^{23}$ Cook and Skikne also reported that serum Iron was suitable only to detect advanced ID as it is subjected to variation in dietary intake, iron therapy, and diurnal variation. ${ }^{23,24}$ Our results were comparable to previous studies. ${ }^{25-27}$

Further discrimination between ID and non-iron deficiency (NID) was based on TSAT\% and ferritin (TSAT $\leq 16 \%$ and serum ferritin $\leq 15 \mu \mathrm{g} / \mathrm{L}$ were identified as ID; TSAT $>16 \%$ and serum ferritin $>15 \mu \mathrm{g} / \mathrm{L}$ were identified as NID). Sixty three out of 200 were ID (31.5\%), and the rest $137 / 200$ were NID (68.5\%). It has been reported that TSAT\% measurements are fairly insensitive as the degree of change with variation in iron stores is small relatively to assay variability. ${ }^{24}$

Serum hepcidin was in the range of 12.14 to $139.89 \mathrm{ng} / \mathrm{mL}$ in this population group and was associated with good appreciable AUC on ROC curve as reported in our previous study. ${ }^{28}$ Reference range of 5.4 to $174.6 \mathrm{ng} / \mathrm{mL}$ was observed among healthy premenopausal female in Australia. ${ }^{29}$ Similarly, reference range of 17.186 to $91.237 \mathrm{ng} / \mathrm{mL}$ for Namibian female blood donor population and 29 to $254 \mathrm{ng} / \mathrm{mL}$ was observed by previous studies. ${ }^{30}$ Galesloot et al also established normal ranges for hepcidin in the Netherlands with median of $4.1 \mathrm{nM}^{21}$

Hepcidin is master regulator of iron homeostasis through its effect on ferroportin; therefore, it gives an accurate estimate of iron bioavailability. Incorporating this biomarker into the present diagnostic arena also requires good correlation with other iron parameters that would be beneficial for clinicians in disease management.

Hence, on correlation study it was observed that serum hepcidin showed significant positive correlation with hemoglobin, serum iron, ferritin and TSAT\% and negative correlation with sTfR and serum transferrin. Similar correlation was seen in premenopausal female and children.,29

Hepcidin and serum ferritin respond same to the change in iron stores and inflammation and this was reflected in the strong correlation between hepcidin and ferritin. Further, changes in ferritin concentration are much slower but hepcidin responses take place in time scale of few hours. This emphasizes understanding of the pathogenic role of hepcidin in various disorder and application in therapeutic intervention. $3,17,31,32$

The specificity of hepcidin concentration as an index of iron status is reflected by its physiology. ID and erythropoiesis lead to suppressed hepatic hepcidin release, ${ }^{32}$ facilitating increased intestinal iron absorption ${ }^{33}$ and release from macrophage stores through intact membrane ferroportin on the basolateral aspect of enterocytes ${ }^{9}$ and macrophages. 


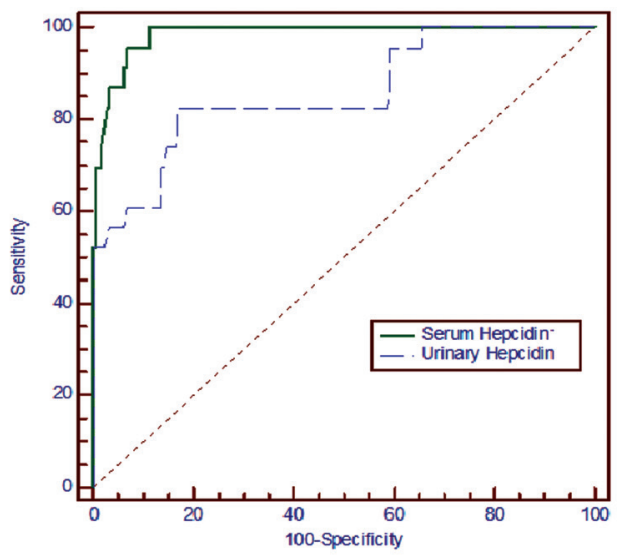

\section{Serum Hepcidin Urinary Hepcidin}

$\begin{array}{ccc}\text { Optical Cutoff } & \leq 15.7 & \leq 199 \\ \text { Sensitivity } & 95.7 & 82.6 \\ \text { Specificity } & 93.2 & 83.1 \\ \text { AUC } & 0.984 & 0.857 \\ \text { Std error } & 0.0075 & 0.0476 \\ \text { P-value } & <0.001 & <0.001\end{array}$

Fig. 3 Receiver operating curve analysis of serum hepcidin $(\mathrm{ng} / \mathrm{mL})$ and urinary hepcidin $(\mathrm{ng} / \mathrm{mg})$ in evaluation of iron status $(n=200)$.

Thus, decreased hepcidin is an essential part of the physiological response to an iron deficit. Ferritin (an index of iron stores), sTfR (an index of erythropoietic marrow iron depletion), and hepcidin (a signal that increased iron is required) each display various aspects of iron metabolism. Thus, combined evaluation of these indices may afford complementary clinical information enhancing patient care. A low hepcidin concentration may predict efficient intestinal absorption of supplemental iron$^{33}$ potentially delineating patients who would benefit most from oral iron therapy.

Decreased hepcidin, together with low TSAT and serum ferritin, is observed prior to a detectable decrease in $\mathrm{Hb}$. In conjunction, hepcidin measurements could improve the screening of IDA before development of hematological manifestations that are relatively late sequelae of IDA.

However, diurnal variation and standardization of assays play an important role in estimation of hepcidin. Further utility of serum hepcidin for diagnosing ID should be confirmed in studies with larger sample sizes to assure enhanced diagnoses and clinical management.

Urinary hepcidin may provide an indirect measure of the circulating hormone hepcidin level. Hence, in present study we further determined urinary hepcidin levels that are less affected by diurnal variation and simple noninvasive collection method. However, urinary hepcidin cannot be used in case of kidney disease. In present study, the reference range observed was 110 to $969 \mathrm{ng} / \mathrm{mg}$ creatinine with mean \pm SD of urinary hepcidin being $368.3 \pm 195.07 \mathrm{ng} / \mathrm{mg}$.

Table 5 Discrimination between ID and NID population based on urinary hepcidin

\begin{tabular}{|l|l|l|l|}
\hline Parameter & ID/ NID & \multicolumn{2}{|l|}{$n=200$} \\
\cline { 3 - 4 } & & $n$ & Percentage \\
\hline $\begin{array}{l}\text { Urinary hepcidin } \\
\leq 199 \mathrm{ng} / \mathrm{mg}\end{array}$ & ID & 49 & 24.5 \\
\hline $\begin{array}{l}\text { Urinary hepcidin } \\
>199 \mathrm{ng} / \mathrm{mg}\end{array}$ & NID & 151 & 75.5 \\
\hline
\end{tabular}

Abbreviations: ID, iron deficiency; NID, non-iron deficiency.
There has been limited studies of urine hepcidin in young females. Urinary hepcidin was observed to be 0.51 to 7.22 intensity/mmol creatinine (mass spectrophotometric estimation) in Bangladeshi women. ${ }^{34}$ However, urinary hepcidin levels of $443.92 \pm 91.84 \mathrm{ng} / \mathrm{ml}$, with range from 344 to 650 $\mathrm{ng} / \mathrm{mL}^{35,36}$ and 0.62 to $6.65 \mathrm{nmol} / \mathrm{mmol}$ creatinine range and cutoff value $\leq 0.94 \mathrm{nmol} / \mathrm{mmol}$ creatinine, were reported in children. Median urinary concentration of $502 \mathrm{ng} / \mathrm{mg}$ creatinine with the range of 71 to 1,762 was reported by Ganz et al in healthy women volunteers. ${ }^{17}$ Therefore, uniform standardization of assays and setting of reference range in different populations may likely help in better prediction of iron status. Similar to serum hepcidin, urinary hepcidin showed significant correlation with iron indices. Present data were in agreement with previous studies. ${ }^{37,38}$

For urinary hepcidin, an AUC of 0.875 was obtained with the best combination of diagnostic sensitivity (82.6\%) and specificity (83.1\%) at a cutoff value of $\leq 199 \mathrm{ng} / \mathrm{mg}$. About $24.5 \%$ of young females were diagnosed to be iron deficient based on urinary hepcidin cutoff value. Reduced urinary hepcidin is a crucial part of the physiological response to an IDA. Decreased hepcidin and serum ferritin along with other routine iron indices are indicators of iron demand. Hence, combined evaluation of Hepcidin along with these iron profile markers may complement each other and enhance diagnosis. Use of urinary hepcidin level may prove as a sensitive, noninvasive investigation that can evaluate iron state in young reproductive females, even in early stages before developing anemia.

One of our limitations in this study was the small number of cases. Detection of urinary hepcidin-25 level in association with other iron profile markers in large prospective studies could strengthen our results.

\section{Conclusions}

Hepcidin can be useful investigation in diagnosing ID in early stages in apparently healthy young females, so that the timely intervention strategies can be started to reduce morbidity. Further larger multicentered prospective study will be necessary to confirm these findings. 


\section{Ethical Approval}

The study was conducted after getting ethical approval from Medical Ethics Committee of SGT university, Gurgaon, Haryana, India.

Shree Guru Gobind Singh Tricentenary University (SGT University), The Faculty of Medicine and Health Sciences (FMHS).

Ethical clearance Reference No: SGTU/FMHS/D./96, Dated March 14, 2016.

\section{Presentation at a Meeting}

A part of research "Study the role of hepcidin in diagnosis of iron deficiency anemia in young females of northern India" published in IJRMS Shaveta, Bansal SK, Patel S. Study the role of hepcidin in diagnosis of iron deficiency anemia in young females of northern India. Int J Res Med Sci. 2020;8(10):3647-51.

\section{Contribution Details}

All the authors have substantial contributions to conception and design, acquisition, analysis, interpretation of data, drafting the article, revising it critically, and final approval of the version to be published.

\section{Source(s) of Support}

In the present study, we haven't received any support in the form of grants, equipment, and/or drugs.

\section{Conflict of Interest}

All authors declare that they do not have any conflict of interest.

\section{Acknowledgment}

We gratefully acknowledge all the participants and staff of SGT Medical College for their support throughout the study.

\section{References}

1 World Health Organization. World-Wide Prevalence of Anaemia, 1993 to 2005. Geneva, Switzerland: World Health Organization; 2008

2 Prevalence of anaemia in women of reproductive age (aged 15-49) (\%) [Internet]. [cited June 14, 2021]. Accessed July 24, 2021 from: https://www.who.int/data/gho/data/indicators/indicator-details/ $\mathrm{GHO} /$ prevalence-of-anaemia-in-women-of-reproductive-age-(-)

3 Choi HS, Song SH, Lee JH, Kim HJ, Yang HR. Serum hepcidin levels and iron parameters in children with iron deficiency. Korean J Hematol 2012;47(04):286-292

4 Zimmermann MB, Hurrell RF. Nutritional iron deficiency. Lancet 2007;370(9586):511-520

5 Kroot JJ, Tjalsma H, Fleming RE, Swinkels DW. Hepcidin in human iron disorders: diagnostic implications. Clin Chem 2011;57(12): 1650-1669

6 Ganz T, Nemeth E. Hepcidin and iron homeostasis. Biochimica et Biophysica Acta (BBA)-. Molecular Cell Research. 2012;1823(09): 1434-1443

7 Ganz T. Hepcidin, a key regulator of iron metabolism and mediator of anemia of inflammation. Blood 2003;102(03):783-788

8 Kemna EH, Tjalsma H, Willems HL, Swinkels DW. Hepcidin: from discovery to differential diagnosis. Haematologica 2008;93(01): 90-97
9 Nemeth E, Tuttle MS, Powelson J, et al. Hepcidin regulates cellular iron efflux by binding to ferroportin and inducing its internalization. Science 2004;306(5704):2090-2093

10 Nemeth E, Ganz T. The role of hepcidin in iron metabolism. Acta Haematol 2009;122(2-3):78-86

11 Ganz T. Hepcidin and iron regulation, 10 years later. Blood. 2011;117:4425-4433

12 Adamson JW. Iron Deficiency and other hypoproliferative anaemias. In: Longo DL, Fauci AS, Kasper DL, Hauser SL, Jameson JL, Loscalzo J, eds. Harrison's Principles of Internal Medicine. 18th ed. New York, NY: McGraw Hill; 2012:844-448

13 Cook JD. Diagnosis and management of iron-deficiency anaemia. Best Pract Res Clin Haematol 2005;18(02):319-332

14 Ganz T, Nemeth E. Iron imports. IV. Hepcidin and regulation of body iron metabolism. Am J Physiol Gastrointest Liver Physiol 2006;290(02):G199-G203

15 Valore EV, Ganz T. Posttranslational processing of hepcidin in human hepatocytes is mediated by the prohormone convertase furin. Blood Cells Mol Dis 2008;40(01):132-138

16 Park $\mathrm{CH}$, Valore EV, Waring AJ, Ganz T. Hepcidin, a urinary antimicrobial peptide synthesized in the liver. J Biol Chem 2001;276(11):7806-7810

17 Ganz T, Olbina G, Girelli D, Nemeth E, Westerman M. Immunoassay for human serum hepcidin. Blood 2008;112(10):4292-4297

18 Muñoz M, Villar I, García-Erce JA. An update on iron physiology. World J Gastroenterol 2009;15(37):4617-4626

19 Hodges VM, Rainey S, Lappin TR, Maxwell AP. Pathophysiology of anemia and erythrocytosis. Crit Rev Oncol Hematol 2007;64(02): 139-158

20 Galesloot TE, Vermeulen SH, Geurts-Moespot AJ, et al. Serum hepcidin: reference ranges and biochemical correlates in the general population. Blood 2011;117(25):e218-e225

21 Galesloot TE, Vermeulen SH, Geurts-Moespot AJ, et al. Serum hepcidin: reference ranges and biochemical correlates in the general population. Blood 2011;117(25):e218-e225

22 De Domenico I, Ward DM, Kaplan J. Hepcidin regulation: ironing out the details. J Clin Invest 2007;117(07):1755-1758

23 Veena A, Sonagra AD, Rekha M, Murthy JP. Study of serum iron, $\mathrm{TIBC}$, transferrin saturation and ferritin in iron deficiency anaemia in tertiary care hospital. IJPBS 2013;3(01):14-23

24 Cook JD, Skikne BS. Iron deficiency: definition and diagnosis. J Intern Med 1989;226(05):349-355

25 Modi S, Sukhwant B. Study of iron status in female medical students. IJBAMR 2013; 2(06):518-526

26 Fayet-Moore F, Petocz P, Samman S. Micronutrient status in female university students: iron, zinc, copper, selenium, vitamin B12 and folate. Nutrients 2014;6(11):5103-5116

27 Stangland JE. Biochemical Markers of Iron Status in Recreational Female Runners. Doctoral dissertation, The Ohio State University; 2013

28 Shaveta, Bansal SK, Patel S. Study the role of hepcidin in diagnosis of iron deficiency anemia in young females of northern India. Int J Res Med Sci. 2020;8(10):3647-3651

29 Pasricha SR, McQuilten Z, Westerman M, et al. Serum hepcidin as a diagnostic test of iron deficiency in premenopausal female blood donors. Haematologica 2011;96(08):1099-1105

30 Gonzo M, Maramba A, Taylor G. Hepcidin testing; establishing reference values for the Namibian blood donor population. Int J Blood Transfus Immunohematol. 2017;7:1-6

31 Ashby DR, Gale DP, Busbridge M, et al. Plasma hepcidin levels are elevated but responsive to erythropoietin therapy in renal disease. Kidney Int 2009;75(09):976-981

32 Peters HPE, Laarakkers CMM, Swinkels DW, Wetzels JFM. Serum hepcidin-25 levels in patients with chronic kidney disease are independent of glomerular filtration rate. Nephrol Dial Transplant 2010;25(03):848-853

33 Young MF, Glahn RP, Ariza-Nieto M, et al. Serum hepcidin is significantly associated with iron absorption from food and 
182 Role of Serum and Urinary Hepcidin Laller et al.

supplemental sources in healthy young women. Am J Clin Nutr 2009;89(02):533-538

34 Schulze KJ, Christian P, Ruczinski I, et al. Hepcidin and iron status among pregnant women in Bangladesh. Asia Pac J Clin Nutr 2008; 17(03):451-456

35 Al Sharkawy SG, El-Kelany AM, Anani MM, El-shahat El, El Sayed $\mathrm{H}$. Urinary hepcidin concentration in assessment of iron homeostasis in pediatrics. The Egyptian Journal of Haematology. 2019; 44(02):105
36 Sanad M, Gharib AF. Urinary hepcidin level as an early predictor of iron deficiency in children: a case control study. Ital J Pediatr 2011;37(01):37

37 Mouhamed H, El Sheimy A, Omran A, Mohamed Y, Helmy F, Ali S. The role of urinary hepcidin in early detection of iron deficiency anemia. Journal of Medicine in Scientific Research. 2018;1(03):173

38 Al-Mazahi MM, Mekky AA, Salam MA, Elfar ES. Urinary hepcidin in diagnosis of iron deficiency anemia. Asian J Clin Nutr 2015; $7: 9$ 